\title{
DRYING CONDITIONS FOR PADDY PROCESSING IN MIXED-FLOW HIGH-CAPACITY PLANT
}

\author{
Filip Mojsovski \\ Faculty of Mechanical Engineering, "Ss. Cyril and Methodius" University in Skopje, \\ Karpoš II bb, P.O. box 464, 1001 Skopje, Republic of North Macedonia \\ filip.mojsovski@mf.edu.mk
}

\begin{abstract}
A b s t r a c t: A research was conducted to obtain information on needed procedures for transforming one universal cereal dryer in special equipment for paddy. Harvested paddy was dried under controlled air conditions in continuous-flow high-capacity grain dryer. The realization of the planned study was carried out in three steps: 1) correction of dryer construction, 2) insertion of intermittent drying process, and 3) selection of correct drying conditions. Intermittent drying process was studied by tempering paddy during its processing. In a drying section two zones system was exploited, zone 1 with air temperatures up to $45^{\circ} \mathrm{C}$, and zone 2 with air temperatures up to $40{ }^{\circ} \mathrm{C}$. In a cooling section air temperatures up to $26^{\circ} \mathrm{C}$ were used. Variations in moisture content, between the grains from two successive horizontal elements of the dryer, were in the range of near one percentage points. In the first horizontal elements of heating section, the variation of moisture content wet basis was two times higher than in the rest horizontal elements of drying section. Correct drying conditions, for local paddy varieties, were selected and are reported.
\end{abstract}

Key words: food drying; paddy; drying conditions

\section{УСЛОВИ НА СУШЕЊЕ ЗА ТРЕТМАН НА ОРИЗОВА АРПА ВО ИНДУСТРИСКА СУШИЛНИЦА СО КОМБИНИРАНО СТРУЕЊЕ}

\begin{abstract}
А п с т р а к т: Спроведено е истражување со цел да се добијат информации за потребните постапки при трансформирањето на една универзална житна сушилница во специјална опрема за оризова арпа. Ожнеаната оризова арпа е сушена, при контролирани состојби на воздухот, во индустриска сушилница со континуиран протек на воздух. Реализацијата на планираната студија беше спроведена во три етапи: 1) приспособување на конструкцијата на сушилницата, 2) воведување сушење со прекини и 3) избирање правилни услови на сушење. Процесот на сушење со прекини е проучуван со менување на температурата на оризовата арпа во текот на нејзиниот третман. Во делот за сушење беше користен систем со две зони, зона 1 со температури на воздухот до $45^{\circ} \mathrm{C}$, и зона 2 со температури на воздухот до $40{ }^{\circ} \mathrm{C}$. Во делот за ладење беа користени температури на воздухот до $26^{\circ} \mathrm{C}$. Промените на содржаната влага во зрната од два сукцесивни хоризонтални елементи на сушилницата беа во опсег од близу еден процент. Во првите хоризонтални елементи од делот за греење промената на содржаната влага по влажна основа беше два пати поголема од онаа во другите хоризонтални елементи од делот за греење. Избрани се оптимални услови за сушење на локалните сорти оризова арпа и се објавуваат.
\end{abstract}

Клучни зборови: сушење на храна; оризова арпа; услови на сушење

\section{INTRODUCTION}

It is certain that rice is among the world basic foods and feeds. The annual world production of paddy was 650 million tonnes in 2007 and 770 million tonnes in 2017 [1].
Paddy hull is removed during the milling process in order to produce white rice. In the milling process approximately $70 \%$ white rice is produced, because the loss for dehulling is up to $30 \%$ [2]. 
Paddy is harvested at high moisture content and must be dried. Drying of grain, in forced convection system, is the most practiced preservation method. Estimation of the quantity of air required to remove the moisture from the dried rice is based on psychrometric [3, 4]. Of all cereals, rice is probably most difficult to process without quality loss.

Immediate drying of the harvested paddy is essential to prevent quality deterioration. The quality characteristics of paddy can be seriously damaged by early harvesting (immature and highmoisture content grain), incorrect combine settings (broken kernels) and rapid drying (stress-cracked kernels). To obtain the desired product quality, the pre and post treatment of dried product is also important. Radical cleaning and correct storage are necessary.

In the five steps grain processing, harvestingdrying-storage-handling-transportation, drying is the duty of a thermal engineer.

Paddy drying is thermal process of simultaneous heat and mass transfer. The kernel is capillaryporous body. The pore, tiny opening trough which fluids may pass, are partially filled with liquid water and partially filed by mixture of air and watervapor. In the thermal drying process, the moisture evaporates and leaves the kernel. The movement of evaporated moisture inside the grain is influenced by capillary forces, but at the kernel surface, partial vapor pressure difference between the water-vapor in the kernel and surrounding air, is driving force. The moisture movement in capillary-porous body due to the diffusion and Earth gravitation is also present, what additionally complicates the understanding of the matter. Existing food drying theory cannot be sufficient to evaluate the drying rate under different drying conditions. It remains to be seen if the solution can be find using laboratory and field tests.

Throughout the harvest season, huge quantities of paddy are available daily and the need for reduction of drying time, favors the use of highcapacity dryers.

In the actual research, tower-type mixed-flow dryer is exploited (Figure 1).

Composed of 17 horizontal elements, with dimension $3 \times 3 \times 1 \mathrm{~m}$, the dryer reaches $26 \mathrm{~m}$ height. The inner construction of the horizontal element provides mixed-flow in the dryer. The relative direction of the air and the grain in this mixed-flow system is a combination of crossflow, concurrent and countercurrent flow. Therefore, the variation in the kernel moisture content is small. This is the major advantage of mixed-flow dryer application.

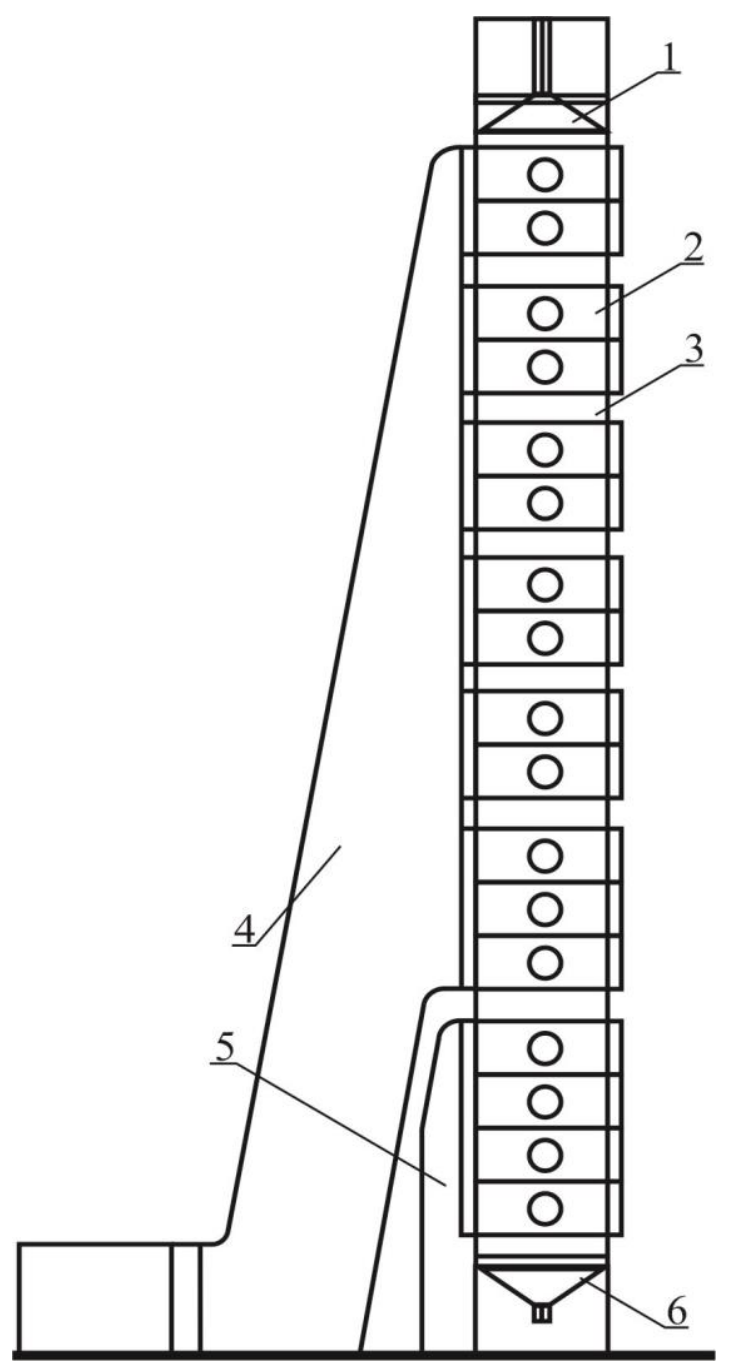

Fig. 1. Tower-type cereal dryer

1 - filling module, 2 - horizontal element,

3 - lower horizontal element, 4 - hot air duct, 5 - cold air duct, 6 - unloading auger

The moist grain kernels, after cleaning, are introduced at the upper side of the dryer, into the drying section and then into the cooling section.

In a drying section heated air carries heat into the paddy mass, to evaporate its moisture and then removes the evaporated water out of the system. The amount of moisture removed from paddy, per horizontal element of drying section, should be controlled and limited.

In a cooling section the ambient air removes heat from the paddy mass and then discharges it, into the environment.

Drying section consists of 13 horizontal elements, each $1 \mathrm{~m}$ high, built-up in six groups, $3+2$ 
$+2+2+2+2$. Every group is separated by $0.5 \mathrm{~m}$ high horizontal element. These five lowers horizontal elements provide the intermittent regime of drying.

Intermittent cereal drying process uses discontinuous heat input. During the pause in the heat supply, the moisture has enough time to be dislocated within the material. This kind of drying process can improve the quality of dried product [5].

Intermittent cereal drying has already wide application in practice.

High-capacity cereal-drying systems improve grain quality as a result of the intermittent drying. A tempering section or tempering period separates two adjoining drying stages. This results in a retention time, adequate to sufficiently reduce the temperature and moisture content gradients in the kernels, before subsequent further drying.

Cooling section consists of 4 horizontal elements, in which the hot, dried grain is cooled with the ambient air, to within $5^{\circ} \mathrm{C}$ of its dry-bulb temperature. During the cooling process, some moisture is also removed.

According to the manufacturer documentation, the actual dryer is designed as universal, for all cereals drying.

\section{OBJECTIVE AND PROCEDURES}

The purpose of this paper is to summarize the results of the efforts to make this type of dryer primarily convenient for paddy drying.

The realization of the planned study was carried out in three steps: 1) correction of dryer construction, 2) insertion of intermittent system of drying, and 3) selection of correct drying conditions.

In the phase of preparation for planned tests, air distribution was modified to enable zonal airflow and uniform air velocities at the entrance of drying room. To satisfy the exact needs of drying process, the drying space was organized as multithermal zone system [6].

Grain cleaner was introduced, as auxiliary but important equipment, one that can enhance the dryer performance. In the case when cleaning is not enough effective, accumulated impurities obstruct the correct grain flow in the horizontal elements of the mixed-flow dryer.

Rice is highly sensitive to amount and intensity of received heat during the drying. The experience, from industrial drying practice, shows that drying rice slowly, with intermittent tempering, is a suitable drying method.

The level of drying air temperature has basic influence on grain drying. Temperature gradients in a kernel, cause expansion in the nonhomogeneous grain material. Drying process in which paddy temperature reaches $38{ }^{\circ} \mathrm{C}$, provoke cracks in the interior of the kernel. Then, in the milling process, the percentage of whole kernels will be not tolerantly low.

Only during the pass-through in the first horizontal elements of drying section, since paddy is still cool and relatively high in moisture, the temperature can be slightly higher.

The resistance to the airflow into drying room is a result of energy lost through friction and turbulence. It depends on three factors: the rate of airflow, the surface and shape characteristics of pad$\mathrm{dy}$, and the realized voids in the horizontal elements during the mutual movement of air and paddy. Paddy has the roughest hull surface of all cereals. Higher rate of airflow was provided by pressure build-up on the air-entrance side.

The airflow rates necessary to dry and cool the grain mass are provided by centrifugal fans. Tests were carried out in order to find the correct fan regime. The airflow, at the entrance of heating and cooling section, was controlled by measurements. At the same measuring points, temperature and relative humidity of air were registered.

The intermittent drying is realized with constructive and functional interventions. All five lower horizontal elements are built as vertical ducts and have not direct drying-air supply. The grain moves within the lower horizontal element but is not heated. The second kind of pause in heating is controlled by unloading auger and heating process. Simultaneously grain movement and heat supply are stopped. Duration of tempering period was evaluated by tests.

Drying conditions ("the combination of dryer construction, dried product state during the process and drying medium state during the process"), were selected as correct, in the case when the dried product was of first-rate quality. Drying conditions were investigated by computer simulation and fieldwork activities [7].

The paddy state in drying process was controlled continuously. The tests procedure contained measurements, visual evaluation and test judging.

Dried material state (initial, zonal and final moisture content and temperature), drying medium 
state (temperature, relative humidity, flow) and dryer function (zonal drying time, energy consumption) were controlled by measurements. The field tests were necessary to verify the expected dried rice quality, reached under specified drying conditions.

Dried paddy state control was realized by sampling in time and space. Measuring platforms were built at the base level of every horizontal element. Sampling tube enables to take specimen from all horizontal elements during the drying process. It is constructed as tube-in-tube device, which collects grains from measuring points for laboratory analysis. The movement of sampling tube into the paddy mass was obstructed because of the tough and abrasive nature of husks. Direct measurement, moisture content determination method, with apparatus based on infra-red radiation, was used in laboratory conditions. Drying medium state was controlled by digital psychrometers and ane- mometers. Attention was concentrated on regime parameters, operation problems, diagnostics and plant efficiency.

\section{RESULTS AND DISCUSSION}

In the period of September to November, when local paddy varieties, Monticelli, Saint Andrew and RS76 are dried, the atmospheric air temperature range, at the location of drying plant, is between 30 and $2{ }^{\circ} \mathrm{C}$. For these temperatures, from the climatic curve, the level of relative humidity is graphically evaluated from 35 to $80 \%$, and enthalpies from 54 to $10 \mathrm{~kJ} / \mathrm{kg}$ [8].

Psychrometric chart, with coordinates of temperature and humidity ratio, was used for convenient graphical illustration of drying air states changes during its heating and humidifying (Figure 2).

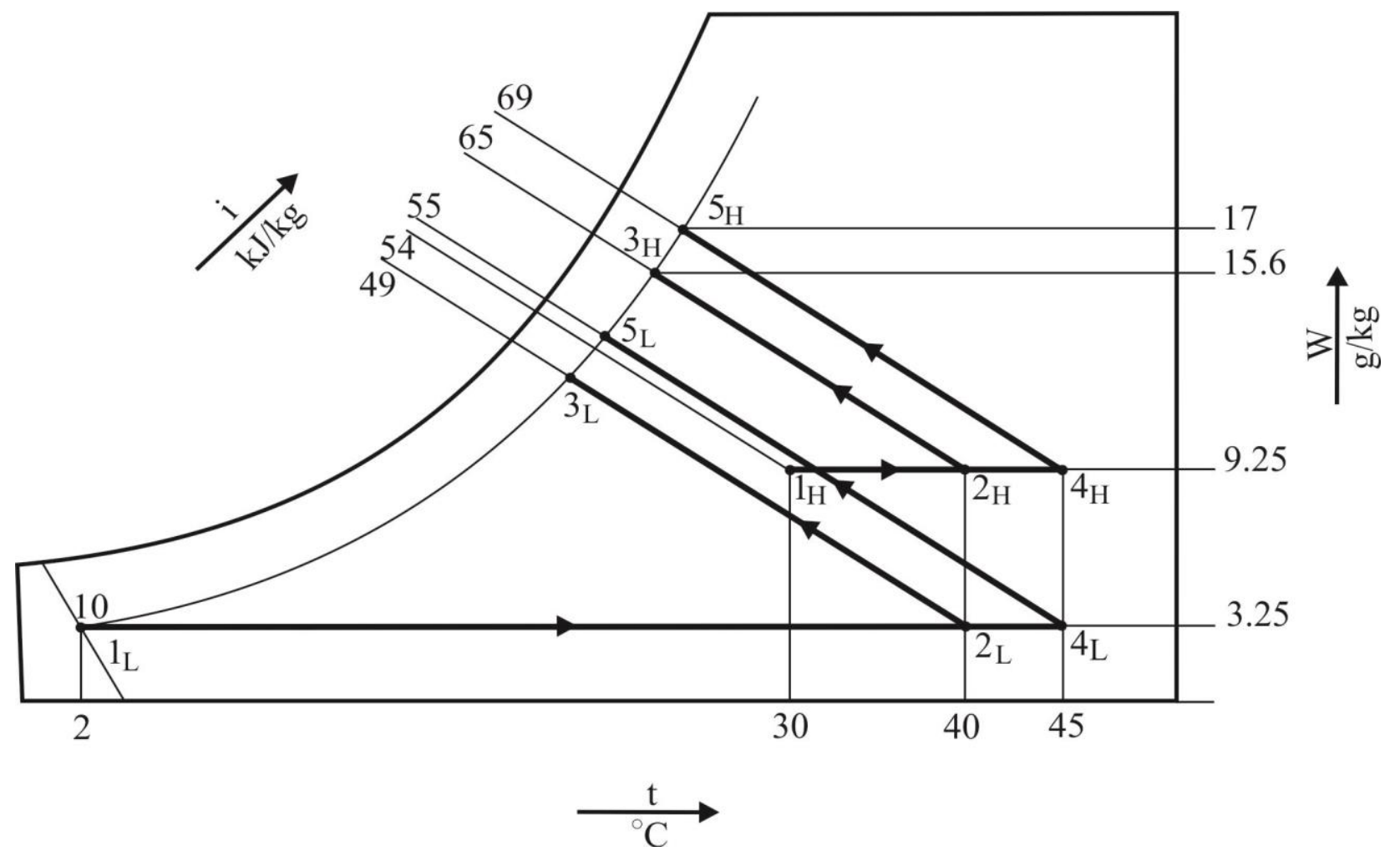

Fig. 2. Psychrometric diagram

The comparison of data, obtained from the psychrometric diagram for the two extreme atmospheric states $\left(2^{\circ} \mathrm{C}, 80 \%\right.$ and $\left.30{ }^{\circ} \mathrm{C}, 35 \%\right)$, shows great difference in needed amount of heating energy, for more than three times, $\Delta i$ for $\left(1_{\mathrm{L}}, 2_{\mathrm{L}}\right)=49$ $-10=39 \mathrm{~kJ} / \mathrm{kg}$, and $\Delta i$ for $\left(1_{\mathrm{H}}, 2_{\mathrm{H}}\right)=65-54=11$ $\mathrm{kJ} / \mathrm{kg}$.
By examination, it was found that the heat demand of the dryer, can be provided by applying paddy husk as fuel. Heating values of up to 15000 $\mathrm{kJ} / \mathrm{kg}$ were obtained, by measuring the heat generated during combustion of local paddy husk in calorimeter. Such an approach was considered as most desirable from an ecological standpoint [9]. 
The option for recirculation, of part of the dryer exhaust air, was examined and abandoned as not attractive. The grain was cleaned before it was dried. The used grain cleaner removed up to $1 \mathrm{~kg}$ weed seed and trash from $100 \mathrm{~kg}$ of processed paddy. The level of examined parameters, relevant for the selection of drying conditions, is presented in Table 1.

\section{Table 1}

The relevant data from field and laboratory tests

\begin{tabular}{|c|c|}
\hline Parameter & Value \\
\hline \multicolumn{2}{|l|}{ 1. Air } \\
\hline \multicolumn{2}{|l|}{ 1.1. Atmosphere, } \\
\hline - Temperature, ${ }^{\circ} \mathrm{C}$ & $2-30$ \\
\hline \multicolumn{2}{|l|}{ 1.2. Drying room } \\
\hline \multicolumn{2}{|l|}{ 1.2.1. First two horizontal elements, } \\
\hline - Temperature, ${ }^{\circ} \mathrm{C}$ & $32-45$ \\
\hline \multicolumn{2}{|l|}{ 1.2.2. Third to thirteenth horizontal element, } \\
\hline - Temperature, ${ }^{\circ} \mathrm{C}$ & $32-40$ \\
\hline \multicolumn{2}{|c|}{ 1.2.3. Fourth to seventeenth horizontal element, } \\
\hline \multicolumn{2}{|l|}{ 2. Paddy } \\
\hline \multicolumn{2}{|l|}{ 2.1. Filling auger: } \\
\hline - Moisture content, wet basis, $\%$ & $16-28$ \\
\hline - Temperature, ${ }^{\circ} \mathrm{C}$ & $12-22$ \\
\hline \multicolumn{2}{|l|}{ 2.2. First two horizontal elements: } \\
\hline - Moisture content, wet basis, $\%$ & $14-23$ \\
\hline - Temperature, ${ }^{\circ} \mathrm{C}$ & $15-28$ \\
\hline \multicolumn{2}{|l|}{ 2.3. Third to thirteenth horizontal element: } \\
\hline - Moisture content, wet basis, $\%$ & $11-15$ \\
\hline - Temperature, ${ }^{\circ} \mathrm{C}$ & $24-36$ \\
\hline \multicolumn{2}{|l|}{ 2.4. Fourteenth to seventeenth horizontal element: } \\
\hline - Moisture content, wet basis, $\%$ & $10-14$ \\
\hline - Temperature, ${ }^{\circ} \mathrm{C}$ & $16-35$ \\
\hline \multicolumn{2}{|l|}{ 2.5. Unloading auger: } \\
\hline - Moisture content, wet basis, $\%$ & $10-14$ \\
\hline - Temperature, ${ }^{\circ} \mathrm{C}$ & $16-35$ \\
\hline
\end{tabular}

Paddy was harvested at an average moisture content, wet basis, between 18 and $30 \%$, during the wet harvest season, and between 16 and $26 \%$, during the dry harvest season. Up to $8 \%$ difference in initial moisture content was registered, between the most mature and least mature kernels.

Variations in moisture content, between the grains from two successive horizontal elements of the dryer, were in the range of one percentage points. In the first horizontal elements of heating section, the variation of moisture content wet basis was two times higher than in the rest horizontal elements of drying section.

Regarding to the temperature regime, at the entrance of drying room, three zones system was selected as a correct one. In the zone 1, the first 
two horizontal elements of drying section, air temperatures up to $45^{\circ} \mathrm{C}$ were used, in the zone 2 , the rest of horizontal elements of heating section, air temperatures up to $40^{\circ} \mathrm{C}$ were used, and in the zone 3 , four horizontal elements of cooling section, temperatures up to $26^{\circ} \mathrm{C}$ were used.

The exit kernel temperature of $35{ }^{\circ} \mathrm{C}$ was not surpassed.

\section{CONCLUSIONS}

Dryer construction was adjusted for zonal paddy drying and requirements of measuring equipment.

True drying intensity was reached with involving intermittent paddy tempering of up to 2 hours.

Correct drying conditions, for local rice varieties, were obtained.

\section{REFERENCES}

[1]FAO (Food and Agricultural Organization of the United Nations), Faostat, Data, 2019.
[2] Brouker, D. B., Bakker-Arkema, F. W., Hall, C. W.: Drying and Storage of Grain and Oilseeds, Van Nostrand Reinhold, New York, USA, 1992.

[3] Gatley, D. P.: Understanding Psychrometrics, American Society of Heating, Refrigerating and Air-Conditioning Engineers, Atlanta, USA, 2013.

[4] ASHRAE (American Society of Heating, Refrigerating and Air-Conditioning Engineers), Handbook Fundamentals, Chapter 1: Psychrometrics, Atlanta, USA, 2013.

[5] Aquerreta, J., Iguaz, A., Arroqui, C., Virseda, P.: Effect of high temperature intermittent drying and tempering on rough rice quality, Journal of Food Engineering, Vol. 80, No. 2, pp. 611-618 (2007).

[6] ASHRAE (American Society of Heating, Refrigerating and Air-Conditioning Engineers), Handbook HVAC Applications, Atlanta, USA, 2011.

[7] Mojsovski, F.: Drying conditions for rice and tomato, International Journal of Mechanical Engineering and Technology, Vol. 5, No. 10, pp. 78-85 (2014).

[8] Mojsovski, F.: Analysis of humidity level in psychrometric thermal processes, $\mathrm{PhD}$ Thesis, Faculty of Mechanical Engineering, Skopje, Macedonia, 2007 (in Macedonian).

[9] Mojsovski, F., Dimitrovski, D.: Thermal conditions for rice parboiling process realised with the use of renewable energy resource, Journal of Environmental Protection and Ecology, Vol. 16, No. 2, pp. 699-704 (2015). 